\title{
THE EFFECT OF USING ENGLISH SLANG WORDS ON STUDENTS' SPEAKING SKILL OF THE YEAR 2018/2019 TENTH GRADE STUDENTS OF SMA NEGERI 1 HINAI KABUPATEN LANGKAT
}

\author{
Nudia Yultisa, Ainun Mardiah \\ STKIP Budidaya Binjai
}

\begin{abstract}
This study aimed to find out whether using English Slang Words affects students' speaking skill of the 2018/2019 tenth grade students of SMA Negeri 1 Hinai Kabupaten Langkat. In this study, using English slang words as the independent variable (X) and students' speaking skill as the dependent variable (Y), with the hypothesis: using English slang words significantly affects students' speaking skill of the 2018/2019 tenth grade students of SMA Negeri 1 Hinai Kabupaten Langkat. The population of this study was the 2018/2019 tenth grade students of SMA Negeri 1 Hinai Kabupaten Langkat. Which consisted of 154 students. The sample was taken buy using cluster random sampling, that consist of 81 students. Then, the sample was divided into two groups, the group taught by using English slang words was as the experimental group and the group taught without Englih slang words was as the control group. The writer used interview test as the instrument of collecting data. The data was analyzed by using t-test formula. Based on the data analysis, it was found that the value of t-observed $\left(\mathrm{t}_{0}\right)$ was higher than the value of $\mathrm{t}$-table, $\left(\mathrm{t}_{\text {observed }}=7,47>\mathrm{t}_{\text {table }}=2,00\right)$. Therefore, the hypothesis proposed by the writer was accepted. In the other words, using English Slang Words significantly affects the students' speaking skill of the 2018/2019 tenth grade students of SMA Negeri 1 Hinai Kabupaten Langkat.
\end{abstract} Keywords: English slang words, speaking skill

\section{INTRODUCTION}

Language is the important thing in social life. People can communicate to others by using language. Language function is to understand what a person intends to the others. By using language, people can share their information, news, and thought to others. It's a very important thing to human in communication in daily life.

Communication is the important thing in human life. Communication is an activity of exchanging and conveying information by speaking or writing among people. It may involve conventional or unconventional signals, may be intentional orunintentional, and may take linguistic or nonlinguistic forms. Everyday people need to communicate with each other, whether directly face to face or indirectly over the phone or sending messages through mail, email, sms, and so on.

Nowadays, communication is more modern and makes people easier to do communicating with their family or their friends which are away from them through instant messages, phone calls, and also video calls. All of those ways of communication can be done easily through cell phones, laptops, or computers. People cannot be separated with the use of their smartphones to communicate or just to open or to update their status on social media like Facebook or Twitter with their relatives or friends. This condition is not good because people are less doing direct 
communication, they prefer to make a call or to send text messages through their smartphone to communicate with someone. Whereas, the best way of communication is direct communication. It is because direct communication enables people to keep stronger relationship with others than indirect communication that leads people to become passive.

The important part of communication is language. People live in a world of language.Studying human language is approaching some might call "human essence", thedistinctive tool which delivers feeling, ideas and opinions through communication. Any child, born everywhere in the world, of any racial, geographical, social,economic heritage, is capable of learning any language to which he or she is exposed. The differencesfound among languages cannot be due to biological reasons. That is why many children are nowtaught other languages beside their mother tounge in school or course by their parents, so in the futuretheir children will find it easier in applying for an overseas school or a job.

In communication, language is the main element. How people use language forcommunication is different from one another. When talking to someone who is older from the speakerpeople use polite ways than when talking to someone who is younger from the speaker. ${ }^{1}$ People's speech reflects not only aspects of their identity such as their ethnicity, age,gender, and social background, it also reflects the contexts in which they are using the language. Theway people talk reflects the formality of those context and the social roles people take inthem.

Language varies from one social group to another social group, from one situation to anothersituation, and from one place to another place. Variation shows that every speaker does not speak thesame way all the time. Language varieties indicate that the speakers are distinct from members ofother groups ${ }^{2}$. Language variety that signifies particular situations of use is calledregisters, it is appropriate for use in particular speech situations. In this research, the focus was only on the languagevariation which could be categorized as slang.

\footnotetext{
${ }^{1}$ Holmes, J, An introduction to sociolinguistic, 2nd Ed, Malaysia: Longman, 2000.

${ }^{2}$ Finegan, E, Language: Its structure and use, 5th Ed, USA: Thomson Wadsworth, 2008.
} 
By using slang words, the writer hopes that the students can be more attractive in speaking English in the class or in daily life. They will know that English is a unique language and interesting to be learned especially in speaking.

The writer also hopes that by using slang words in daily life, it will increase the students' speaking skill.

But the problem is, firstly, the students' understanding about speaking English are still low. Secondly, the students rare to speak English in the class. Thirdly, the students interest in speaking English are still low. Forthly, the speaking approaches in the class are monotonous. Fifthly, the students have less attraction in speaking English. So, the writer hopes that by using this research of Slang Words, will attract the students' interest in studying English especially in speaking.

Slang becomes the part of language variation because of the need to adapt to new or differentaspects of society and factor of social prestige. Although slang is not taught in the curriculum, it doesnot make its existence fades away. It even becomes popular among young people. Slang is informal words or phrases and commonly used in speech between people from the same social group or whowork together, it is not suitable for formal contexts and is often not in use for long.

The popularity of slang nowadays makes it an interesting object to study. It will be interestingto find out what types of slang words that students usually use, what factors or media that influenceyoung people to use slang and also the reason behind the use of slang.

Learning any foreign language has to do with the four skills that have to be mastered. The four skills are listening, speaking and listening (oral skills) are said to relate to language expressed through the aural medium. Reading and writing are said to relate to language expressed through the visual medium (written symbol). Another way of representing these skills is by reference not to the medium but the activity of the language user. Therefore, speaking and writing are said to be active or productive skills, where as listening and reading are said to be passive or receptive skills.

Speaking is to utter words orally, talk; to communicate as by talking; to make a request; to make a speech. ${ }^{3}$ Skill is ability to do something well. ${ }^{4}$ Speaking is a skill which deserves attention every bit as much as literary skills, in both first and second language. To most people, mastering the speaking skill is the single most important aspect of learning a second or foreign language, and success is measured in terms of the ability to carry out a conversation in the language. ${ }^{5}$ Speaking is so much a part of daily life that people take it for granted. The average person produces tens of

\footnotetext{
${ }^{3}$ David Nunan, Guralnik, Language Teaching Methodology a Textbook for Teachers, NY: Phoenix Ltd, 1995, p. 593.

${ }^{4}$ Oxford University Press, Oxford Learner's Pocket Dictionary, New York: Pindar Graphies Origination Scarborough, 1995, p. 403.

${ }^{5}$ David Nunan, Guralnik, loc. cit., p. 39
} 
thousands of words a day, although some peoples, like auctioneers or politicians-may produce even more than that. So natural and integral is speaking that people forget how they once struggled to achieve this ability-until, that is, they have to learn how to do it all over again in a foreign language. ${ }^{6}$ Speaking in a second or foreign language has often been viewed as the most demanding of the four skills. When attempting to speak, learners must master their thoughts and encode those ideas in the vocabulary and syntactic structures of the target language. Depending on the formality and importance of the speech situation (and their own personal linguistic propensities), the learners may also attempt to monitor their output. In conversations and otherinteractive speech events, the speakers must attend to the feedback from their interlocutors and observe the rules of discourse used in the target culture. Phonological considerations add to the difficulty of the task, especially for adult learners, as speakers strive to achieve "good" pronunciation. The speed of such interaction is also an issue because there may not be adequate time for processing either outgoing speech or incoming messages at the typical rate of native-speaker interaction. All of these factors combine to make speaking in a second or foreign language a formidable task for language learners. Yet for many people, speaking is seen as the central skill. The desire to communicate with others, often face to face and in real time, drives people to attempt to speak fluently and correctly. There is a dynamic tension caused by the competing needs for fluency and accuracy during natural speech. People can define speaking as the way to carry out our feeling through words, conversation with other. Speaking also used to communicate as by talking, to make a request, to make a speech. It means that they always use it in their life, because without speaking they will be a dumb and never know everybody's means.

${ }^{7}$ Slang as very casual or writing words, expressions, or usages that are casual, vivid, racy, or playful replacements for standard ones, and are often short lived. Slang is a kind of language especially occurring in casual and playful speech, usually made up of short lived coinages and raciness, humor, or irreverence. Slang is a type of language that consists of words and phrases that are regarded as very informal and are more common in speech than writing, is typically restricted to a particular context or group of people. From these definitions of slang define slang as a casual language, made up of short lived coinages, raciness, and humor. Slang is used within a particular group or set of people.

However, "Slang isn't 'in' words; it is an extrinsic feature of their use adapted by speakers to very precise human social and aesthetic needs and aspirations. In fact, at its origin, slang appears to have been used, not to label words, but to identify an attitude and etc.

\footnotetext{
${ }^{6}$ Scott Thornbury, How to Teach Speaking, Longman, Pearson education limited, 2005, p. 1.

${ }^{7}$ Adams, Michael. Slang: The People's Poetry. New York: Oxford UP, 2009, Print.
} 
Slang is created through the following processes: Combining: Combining morphemes, ${ }^{8}$ the most productive way to make new words in the English language, can involve combinations of all free morphemes, free and bound morphemes, and occasionally all bound morphemes.

1) Combining processes:

Include compounding, prefixing, and suffixing.

a) Compounding: the process of combining more than one free morpheme (bonehead, foureyes, photobomb)

b) Prefixing: the process of attaching a bound morpheme at the head of an already existing word (inaccessible, unfriend, hyperlink)

c) Suffixing: the process of creating a new word by attaching a bound morpheme to the foot of an already existing word (yoked, hankering, reckon, fishy, shady, smokin).

d) Infixing: Dividing a word by inserting a bound morpheme in the middle (absobloodylutely)

2) Shortening:

Existing English words can be shortened to form new words in four common ways.

a) Alphabetism: when the words is formed from the initials of a phrase and the word is pronounced as the resulting sequence of letters (LOL, YOLO)

b) Acronymy: groups of words shortened to initials and then pronounced as though they were merely letters in a typical word (AIDS, RAM, UNICEF)

c) Clipping: when a word looses an element next to the root or base (fabo, insta, rad, sista, bro)

d) Backformation: a new word is formed by removing an affix from a word to form a word that never existed before (diagnosis, burglar)

3) Blending:

Joining two or more words, at least one of which must be clipped (internet, smog, motel, brunch)

4) Shifting:

When a word employed in one lexical category moves into another category (text, e-mail, figure, game, down, minute)

5) Reduplication:

Repeating a morpheme (knock-knock, no-no, hunkey dory, okie dokie)

6) Borrowing:

Borrowing words from other languages(mansion, teepee, wigwam, igloo, bungalow) ${ }^{9}$

\footnotetext{
${ }^{8}$ Curzan, Anne, and Michael Adams, Special Focus: Slang and Creativity, How English Works: A Linguistic Introduction, 3rd ed. N.p.: Pearson Education, 2012. 120-21, Print.
} 
A hypothesis is the researcher' prediction of the research findings, statement of the research expectations about the relation among the variables in the research topic. ${ }^{10}$

Therefore:

(Ha) in this study are as follows, "There is an effect of Using English Slang Words on Students' Speaking Skill of The Year 2018/2019 Tenth Grade Students of SMA Swasta Pesiapan Stabat Kabupaten Langkat"

(Ho) in this study are as follows "There is no effect of Using English Slang Words on Students' Speaking Skill of The Year 2018/2019 Tenth Grade Students of SMA Swasta Pesiapan Stabat Kabupaten Langkat".

There is an effect of of using english slang words on students' speaking skill of the year 2018/2019 tenth grade students of SMA Swasta Pesiapan Stabat Kabupaten Langkat”.

\section{RESEARCH METHODOLOGY}

This study was conducted at SMA Negeri 1 Hinai Kabupaten Langkat. It was a formal education institution located at Jalan Olahraga Dusun 3 Sosial Kecamatan Hinai Kabupaten Langkat. The reason why the writer choosed this school as the object of research it was suitable to conduct a research because the location of the school was not far from the writer's home.

This research was an experimental or quantitative that means there was a certain experiment applied to sample. In conducting this study, the writer applied experimental research design which needs two groups being experimented, one was control group and the other was experimental group. The experimental group was given the treatment by using Slang Words as the media in speaking and the control group without any media of was given convensional method.

\begin{tabular}{|c|c|c|c|}
\hline Group & $\begin{array}{c}\text { Pre- } \\
\text { test }\end{array}$ & Treatment & $\begin{array}{c}\text { Post- } \\
\text { test }\end{array}$ \\
\hline Experimental & $\checkmark$ & $\begin{array}{c}\text { Teaching by } \\
\text { using Slang } \\
\text { Words }\end{array}$ & $\checkmark$ \\
\hline Control & $\checkmark$ & $\begin{array}{c}\text { Teaching by } \\
\text { using } \\
\text { traditional } \\
\text { method }\end{array}$ & $\checkmark$ \\
\hline
\end{tabular}

\footnotetext{
${ }^{9}$ Danesi, Marcel, The Forms And Functions Of Slang Semiotica 2010.182, 2010: 507-517. Communication \& Mass Media Complete. Web. 22 Feb, 2014.

${ }^{10}$ L. R. Gay, Geoffrey E. Mills, Peter W, Airasian, Educational Research: Competencies for Analysis and Applications, New Jersey: Pearson Education Inc, 2009, p.71.
} 
Sample

“Apabila sampel kurang dari 100 lebih baik semua, maka penelitiannya populsi. Jika sebaliknya maka dapat di ambil 10-15\% atau 20-25\% atau tergantung pada kemampuan peneliti dilihat dari segi waktu, tenaga dan dana." Suharsimi statement. The writer took two classes of tenth grade students of SMA Negeri 1 Hinai Kabupaten Langkat.

Considering this, the writer use the cluster random sampling to take the sample. So, the writer take two classes, it means X-1 class and X-2 class as the sample. The number of students in X1 30 students and the number of students in X 230 students. So the total number of sample is 40 students.

\begin{tabular}{|c|c|c|}
\hline Class & Class & Total Number \\
\hline X-1 & Experiment Class & 43 \\
\hline X-2 & Control Class & 38 \\
\hline Total number of Sample & & 81 Students \\
\hline
\end{tabular}

The variable of the study in this experimental study are grouped into two types:

1. Independent varible, and

2. Dependent variable

Independent Variable $(\mathrm{X})$ is the factor which is measured, manipulated, or selected by experimenteer to determine is relationship to observed phenomenon. Dependent Variable (Y) is the factor which is observed and measured to determine the effect of the independent variable (X). There are two variables of the study, namely Slang Words and the students' speaking skill.

In order for the researcher to collect data on the students' speaking skill, the writer prepared speaking test as the instrument. In this case, the writer uses interviewing to the students one by one. The test will be given to the sample and the results are gathered as the data of this study. Those test consists of some of slang words, because the writer wants to classify the students' skill in speaking by using slang words.

Instrument for collecting data was designed in order to see the result of the study. The research data was the result of students score that identify speaking skill by using slang words and stuents who not use any strategy to identify reading ability.A good instrument must require two important conditions; be valid and reliable. ${ }^{12}$

\footnotetext{
${ }^{11}$ Suharsimi, Arikunto, Prosedur Penelitian Suatu Pendekatan Praktik, Jakarta: Rineka Cipta, 2010. ${ }^{12}$ Ibid., p. 144.
} 


\begin{tabular}{|c|c|c|c|}
\hline No. & \multicolumn{2}{|c|}{ Aspect of Speaking } & Score \\
\hline 1 & Grammar & $\begin{array}{l}\text { Describing the } \\
\text { answer } \\
\text { gramatically } \\
\text { correct } \\
\text { Small mistakes in } \\
\text { the use of } \\
\text { grammar }\end{array}$ & $\begin{array}{l}15 \\
15\end{array}$ \\
\hline 2 & Vocabulary & $\begin{array}{lr}\text { Using } & \text { many } \\
\text { words } & \text { in } \\
\text { describing } & \\
\text { Using a } & \text { few } \\
\text { words } & \text { in } \\
\text { describing } & \end{array}$ & $\begin{array}{l}15 \\
15\end{array}$ \\
\hline 3 & Fluency & $\begin{array}{l}\text { A well fluency } \\
\text { A well fluency } \\
\text { with disruption }\end{array}$ & $\begin{array}{l}15 \\
15\end{array}$ \\
\hline & Maxim & n Score & 90 \\
\hline
\end{tabular}

\section{Pre Test}

Pre test is a form of statement that the teacher told the students before starting a lesson. The questions is usually done by the teacher at the beginning of the lesson. Pre test is given for the purpose of knowing whether any of the students already know about the material being taught. As for benefit of the held pretest was to know the initial skill of the students about the lesson delivered.

\section{Post Test}

Post test is a form of questions given after the lesson or material has been delivered. Postest is gave for the purpose of whether the students have understood the material that has just been gave to the students. The benefits of holding this post test is to gain an idea of the skill achieved after the end of the lesson's delivery. The result of this post test is compared with the result of pretest that has been done so that will be known how far improvement of result learn from teaching which have been done.

Since the study is an experimental research, the writer apply the t-test to analyze the data.

The t-test is the most commonly used method to evaluate the differences in means between two groups. ${ }^{13}$

The formula of t-test is:

$$
\mathrm{T}_{\mathrm{o}}=\frac{X_{1}-X_{2}}{\sqrt{\left[\frac{x_{1}^{2}+x_{2}^{2}}{n_{1}+n_{2}-2}\right]\left[\frac{1}{n_{1}}+\frac{1}{n_{2}}\right]}}
$$

\footnotetext{
${ }^{13}$ Pablo E. Subong, et. Al, Statistics For Research, Quezon City: Rex Printing Company, Inc., 2005 p. 92.
} 
Where:

$\mathrm{X}_{1=}$ the aritmetical mean of experimental group

$\mathrm{X}_{2}=$ the aritmetical mean of control group

$\mathrm{x} 1=$ the standard deviation of experimental group

$\mathrm{x} 2=$ the standard deviation of control group

$\mathrm{n}_{1}=$ the number of students in the experimental group

$\mathrm{n}_{2}=$ the number of students in the control group

Hypothesis statistical was a statement or allegation regarding one or more of the population. To test the hypothesis, the writer uses T-test and calculate the data. And then, the criteria will used as follows:

1. If $\mathrm{t}$ observed $>\mathrm{t}$-table (to) Ha (null hypothesis) is accepted. It means that the rates of mean score of the experimental group are higher than the control group.

2. If $\mathrm{t}$ observed < t-table (to) Ha (null hypothesis) is rejected. It means that the rates of mean score of the experimental group are lower than the control group.

\section{THE DATA AND DATA ANALYSIS}

After conducting the pre-test and post-test to the control group and experimental group, it was obtained the students' scores from the data which had been collected.

From the score of the tables above, the following data were obtained.

$\begin{array}{lll}\mathrm{X}_{1} & =8,95 \\ \mathrm{X}_{2} & =3,94 \\ \mathrm{X}_{1}{ }^{2} & =125,59 \\ \mathrm{X}_{2}{ }^{2} & =595,05 \\ \mathrm{n}_{1} & =43 \\ \mathrm{n}_{2} & =38\end{array}$

The data showed from tables above, than were calculated and analyzed by using the t-test formula:

$$
\begin{aligned}
& t=\frac{X_{1}-X_{2}}{\sqrt{\left[\frac{X_{1}^{2}+X_{2}^{2}}{n_{1}+n_{2}-2}\right]\left[\frac{1}{n_{1}}+\frac{1}{n_{2}}\right]}} \\
& t=\frac{8,95-3,94}{\sqrt{\left[\frac{125,59+595,05}{43+38-2}\right]\left[\frac{1}{43}+\frac{1}{38}\right]}}
\end{aligned}
$$


$t=\frac{5,01}{\sqrt{\left[\frac{720,64}{79}\right]-[0,05]}}$

$t=\frac{5,01}{\sqrt{9,12 \times 0,05}}$

$t=\frac{5,01}{\sqrt{0,67}}$

$t=\frac{5,01}{0,67}$

$t=7,47$

After calculating the data above, it shows that the critical value is 7,47 . Then, it is consulted to the t-table of distribution and in the df (degree of freedom) of $79\left(\mathrm{n}_{1}+\mathrm{n}_{2}-2\right.$ or $\left.43+38-2\right)$. The $\mathrm{t}$ table shows that $t$-table $\left(t_{t}\right)$ is 2.00 for $5 \%$ and 2.66 for $1 \%$.

Based on the calculation of the data, the critical value or t-observed $\left(\mathrm{t}_{0}\right)$ is higher than the value of t-table $\left(t_{0}=7,47>t_{t}=2,00\right)$. It means that the alternative hypothesis is accepted. In other words, using English Slang Words significantly affects speaking skill of the 2018/2019 tenth grade students of SMA Negeri 1 Hinai Kabupaten Langkat.

\section{CONCLUSIONS AND SUGGESTIONS}

\section{A. Conclusion}

From the result of the data analysis in the previous chapter, the writer compose a conclusion that in testing the hypothesis, the value of $\mathrm{t}$-observed $(\mathrm{t} 0)$ is higher than the value of $\mathrm{t}$-table, $(\mathrm{t} 0=$ $7,47>\mathrm{tt}=2,00)$. Therefore, the hypothesis proposed by the writer is accepted. In other words, using English Slang Words significantly affects speaking skill of the 2018/2019 tenth grade students of SMA Negeri 1 Hinai Kabupaten Langkat.

\section{B. Suggestion}

From the conclusion stated above, the writer would like to offer some suggestions with the result of this study. The suggestions are:

1. Understanding the English slang words will uniquely brings an important value in achieving English specially to speaking skill. Therefore, the students should improve their understanding of English. 
2. The students also should do more exercises of English speaking test in order to enhance their speaking skill.

3. The teacher should motivate the students to read and practice more.

4. In teaching speaking, the teacher should provide interested material or technique in order to make the students more active in learning English specially to speaking.

5. Finally, the result of this study can make the contribution for developing a better educational world in the future.

\section{REFERENCES}

Arikunto Suharsimi, 2010. Prosedur Penelitian Suatu Pendekatan Praktik, (Jakarta: Rineka Cipta).

Adams, Michael, 2009. Slang: The People's Poetry. New York: Oxford UP Print.

AM. Sardiman, 2004. Interaksi dan Motivasi Belajar Mengajar (Jakarta: Grafindo Persada)

Curzan, Anne, and Michael Adams, 2012. Special Focus: Slang and Creativity. How English

Works: A Linguistic Introduction. 3rd ed. N.p.: Pearson Education, 120-21. Print.

Danesi, Marcel. 2010. The Forms And Functions Of Slang. Semiotica $2010.182 \quad 507-$

517. Communication \& Mass Media Complete. Web. 22 Feb. 2014.

David Nunan, Guralnik, 1995. Language Teaching Methodology a Textbook for Teachers, (NY: Phoenix Ltd.).

E. Winkel,. 2009. Psikologi Pendidikan . (Jakarta: Gramedia).

Finegan, E. 2008. Language: Its structure and use. 5th Ed. USA: Thomson Wadsworth.

Holmes, J. 2000. An introduction to sociolinguistic. 2nd Ed. Malaysia: Longman.

Jack C. Richards, 1994. New Ways in Teaching Speaking, (USA: Pantagraph Printing, Bloomington, Illinois).

Jeremy Harmer, 2001. The Practice of English Language Teaching, (Great Britain: Pearson Education Limited), 3rd Ed.

Jo McDonough and Christopher Shaw, 1993. Materials and Method in ELT; A Teacher's Guide, (UK: Blackwell Publishing Ltd).

L. R. Gay, Geoffrey E. Mills, Peter W. Airasian, 2009. Educational Research: Competencies for Analysis and Applications, (New Jersey: Pearson Education Inc).

Oxford University Press, 1995. Oxford Learner's Pocket Dictionary, (New York: Pindar Graphies Origination Scarborough).

Pablo E. Subong, et. al. 2005. Statistics For Research, (Quezon City: Rex Printing Inc.,) 